\title{
Geochemical and statistical approach for evaluation of heavy metal pollution in core sediments in southeast coast of India
}

\author{
*B. R. R. Seshan; U. Natesan; K. Deepthi \\ Centre for Environmental Studies, Anna University Chennai, Chennai - 600 025, India \\ Received 16 October 2009; ～revised 6 February 2010; accepted 28 February 2010; avaiable online 1 March 2010
}

\begin{abstract}
Industrialization coupled with urbanizaton has led to stress in the Buckingham Canal which runs parallel to Bay of Bengal at a distance of around $1 \mathrm{~km}$ from the coastline. 4 sediment cores were collected along Ennore - Pulicat stretch to determine acid leachable trace metal concentration. Core samples were collected using gravity corer. The cores were sliced horizontally at $2.5 \mathrm{~cm}$ to determine the grain size, sediment composition, $\mathrm{pH}$, organic matter, calcium carbonate, acid leachable trace metals; cadmium, chromium, copper, lead, zinc. The trace metals were extracted using acid mixture containing hydro fluoric acid, nitric acid and sulphuric acid and analysed by atomic emission spectrophotometer. In an attempt to infer anthropogenic input from geogenic input, several approaches including comparison with sediment quality guidelines - ecotoxicological sense of heavy metal contamination and classification by quantitative indexes such as geoaccumalation index, anthropogenic factor, enrichment factor, contamination factor and degree and pollution load index was attempted. Grain size analysis and sediment composition of core samples shows Ennore is sandy in nature having a neutral pH. Organic matter enrichment is observed to a higher extent in core 3. Core 2 at a depth of $5 \mathrm{~cm}$ shows organic matter of $9.4 \%$. calcium carbonate is totally absent at the surface sediments in core 2. Cores collected within the canal showed a higher heavy metal concentration than the cores collected from Pulicat lagoon and $2 \mathrm{~km}$ into the Ennore Sea. The trace metal concentration for cadmium, lead and zinc in Ennore does not pose a threat to the sediment dwelling fauna whereas chromium and copper are likely to pose a threat. Quantitative indexes place Ennore under moderately polluted. Ennore is likely to face a serious threat of metal pollution with the present deposition rates unless stringent pollution control norms are adopted.
\end{abstract}

Keywords: Core; Depth; Ennore; Pollution; Sediment; Trace metals

\section{INTRODUCTION}

Heavy metals are one of the serious pollutants in natural environment due to their toxicity, persistence and bioaccumulation problems (Pekey, 2006; Nouri et al., 2006). The impact of anthropogenic perturbation is most strongly felt by estuarine and coastal environments adjacent to urban areas (Nouri et al., 2008). Heavy metals from incoming tidal water and fresh water sources are rapidly removed from the water body and deposited onto the sediments (Tam and Wong, 2000; Samarghandi et al., 2007). Over the last decades, the study of sediment cores has shown to be an excellent tool for establishing the effects of anthropogenic and natural processes on depositional environments. (Vinodhini and Narayanan, 2008; Nadia, 2009). Most of the contaminants can leave their finger prints in sediments. The only condition is the stability within sedimentary column, i.e. no or insignificant post-

*Corresponding Author Email: mbseshu@rediffmail.com Tel.: +91 98842 51435; Fax: +91 4424472547 depositional mobility is allowed (Tam and Wong, 2000). Sediment analysis offers certain advantages over water analysis for the control and detection of metal pollution in estuaries (Forstner and Wittman, 1983; Luamo, 1990), although its metal concentrations can also fluctuate over time (Araujo et al., 1988) and it was observed the rate of change is well below that of the water (Boyden et al., 1979). On the other hand, surface sediment often exchanges with suspended materials, thereby affecting the release of metals to the overlying water (Zvinowanda et al., 2009). Therefore, the top few centimetres of the sediments reflect the continuously changing present-day degree of contamination, whereas the bottom sediments record its history.

Ennore has now become a major industrial complex. Metals are introduced into Ennore from domestic waste, industrial effluent, urban run-off, atmospheric deposition, as well as upstream run-off accumulate into the sediments. There is little information, however, on 
the impact of these industrial facilities on the environmental loading of heavy metals and particularly the extent to which marine and estuarine sediments have been contaminated by metal-rich waste discharges. The main objective of this study is to examine the metal concentrations in sediment cores along the Buckingham Canal, Ennore. Therefore, the study will attempt to evaluate the extent of heavy metal contamination from the surface to the bottom sediments and the degree to which heavy metals are influenced by other sedimentological parameters such as grain size, $\mathrm{pH}$, sediment composition, and organic matter. The study was carried out for a period of nine months from June 2008 to February 2009. Analysis was carried out in Centre for Environmental Studies, Anna University Chennai. Heavy metals were analysed at Centre for Advanced Studies in Marine Biology, Parangepettai.

\section{MATERIALS AND METHODS}

Study area

Ennore Creek (Fig. 1) located in the north eastern part of Chennai City, Tamil Nadu is spread over an area of $4 \mathrm{~km}$ along the coast of Bay of Bengal. The creek lies between Chennai City and Pulicat Lagoon which is $40 \mathrm{~km}$ North of Chennai city (Latitude $13^{\circ} 15^{\prime} \mathrm{N}$ and Longitude $80^{\circ} 19^{\prime} \mathrm{E}$ ). Ennore Creek is a fresh/brackish water system, which is nearly $800 \mathrm{~m}$ wide and elongated in a NE-SW direction. Ennore Creek is complex, the average depth rarely exceeding $5 \mathrm{~m}$ in the non-monsoon period, being fed by Kortalaiyar River and the Buckingham Canal; it is also connected to the Pulicat brackish water lake on the northern side. Ennore is one of the major industrial regions of India, having two thermal power plants - North Chennai Thermal Power Station and Ennore Thermal Power Station both of them drawing coolant water from the creek. Manali industrial complex and the recently built Ennore satellite port are located in the northern section of the creek. The Buckingham Canal stretches as the Ennore creek in the north to Cooum River in the south and further southwards from there on. Several discharges enter this stretch of the Buckingham Canal from industrial sites such as Madras Refineries Ltd., (MRL), Indian Oil Corporation etc. Municipal discharges also enter Ennore through a number of drains from the north Chennai area.
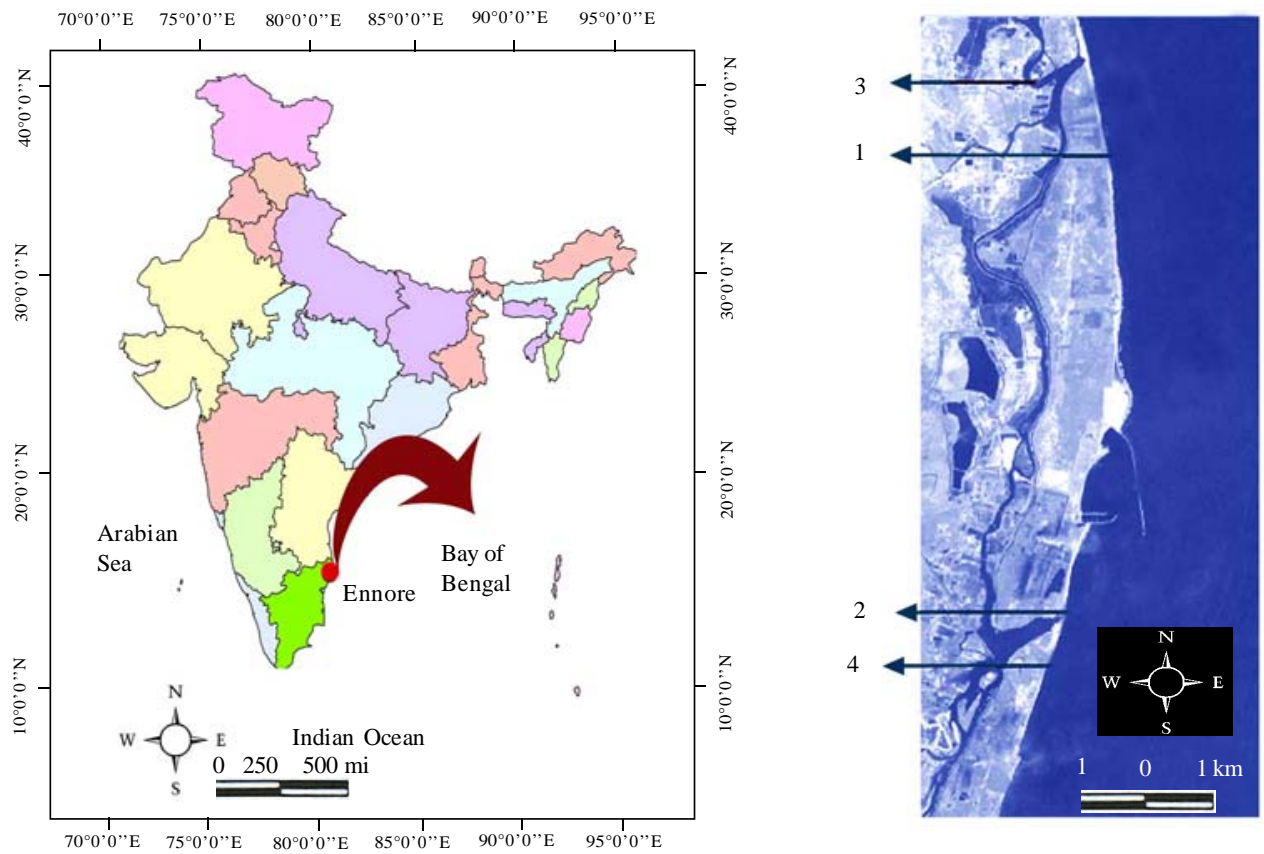

Fig. 1: Location of core sediment sampling station in Ennore, Bay of Bengal 


\section{Core collection}

Four cores were collected along Ennore to Pulicat stretch (Fig. 1) each depicting an environment which is subjected to a of type anthropogenic stress. Aquafarms are situated along the banks of the canal, near Kattupalli region. There are a large number of aquafarms which run on a small scale basis. All these aquafarms draw water from and discharge their wastewater into the canal. The pollution from aquafarm discharges is less compared to the pollutant contribution from industrial discharges from the surrounding Ennore complex. Core 1 was collected near aquafarm discharge $\left(13^{\circ} 21.419^{\prime} \mathrm{N}\right.$ and $\left.80^{\circ} 19.923^{\prime} \mathrm{E}\right)$. Industrial discharges are seen towards the southern side of the creek. Industrial discharges are loaded with sludge; thereby there is a notable reduction in the free flow of water almost forming a cess pool of stagnant water. Core 2 was collected from the industrial discharge location $\left(13^{\circ} 13.413^{\prime} \mathrm{N}\right.$ and $\left.80^{\circ} 19.139^{\prime} \mathrm{E}\right)$. Two cores were collected from an area apparently unaffected by anthropogenic discharges viz. Pulicat lagoon $\left(13^{\circ} 24.411^{\prime} \mathrm{N}\right.$ and $\left.80^{\circ} 19.505^{\prime} \mathrm{E}\right)$ and Ennore Sea (1314' 5'.04N and 8020'39' .33). Core 3 was retrieved from Pulicat area which is located further north from Ennore can be said to relatively pristine as there is only limited or almost no disturbances from human activities, and is considered as a reference point for this study. Core 4 was collected at a distance of $2 \mathrm{~km}$ from the coast into Bay of Bengal to determine if the pollutants from the creek have dispersed into the sea and deposited onto the marine sediments.

Sediment cores (Acid washed PVC pipe of $1 \mathrm{~m}$ length $\mathrm{X} 10 \mathrm{~cm}$ diameter) were collected from a boat on 18.7.2008. The sampling stations determined by GARMIN III global positioning system (GPS). The cores were inserted into the water-sediment interface and pushed to ensure that it reached maximum depth. The cores were slowly retrieved back, closed with its cover immediately and marked as to which is the upward direction. Water depth was measured using a tide pole. Salinity, temperature and dissolved oxygen (DO) of surface water were recorded in the field using a probe as follows:- DO was measured using WTW Oxi 330i / SET, salinity using Cyberscan Con / TDS with $0.1 \mathrm{mS}$ resolution and temperature was measured using a standard thermometer. Core from Ennore Sea was collected on 05.06.2008 with the help of National Institute of Ocean Technology (NIOT) research vessel Sagar Purvi using a gravity corer. All the cores were transported in a vertical position and frozen for a period of 4 days in vertical position. The cores were sliced at $2.5 \mathrm{~cm}$ increments and the sediment samples were stored in clean labelled polythene covers. Subsamples obtained from core 1, 2, 3 and 4 were 15, 16, 15 and 8, respectively (Table 1 ).

Prior to the analysis, all the sediment samples were dried at $70-80{ }^{\circ} \mathrm{C}$ for $48 \mathrm{~h}$ using hot air oven. The shells in the sediment were handpicked. Raw samples were used to determine grain size and sediment composition. Part of the sample was powdered using agate mortar to estimate calcium carbonate, organic matter and heavy metals. Sediment composition was determined following Krumbein and Pettijohn (1938) method. Grain size analysis was done using a set of 10 sieves ranging from $2000 \mathrm{~mm}$ to $45 \mu$ for $15 \mathrm{~min}$ using Rotop sieve shaker (Folk and Ward, 1957). GRADSTAT software was used to find out about the nature of the sediments. $\mathrm{pH}$ of the sediment samples were determined using $\mathrm{pH}$ meter. Calcium carbonate and organic matter were analyzed by adopting the procedure of Loring and Rantala (1992) and Gaudette et al. (1974), respectively. Geoaccumalation index was calculated using an equation given by Müller (1979). $\mathrm{I}_{\text {geo }}=\log _{2}\left(\mathrm{C}_{\mathrm{n}} / 1.5 *\right.$ $B_{n}$ ). Anthropogenic factor (AF) was calculated for the cores collected. $\mathrm{AF}=\mathrm{C}_{\mathrm{s}} / \mathrm{C}_{\mathrm{d}}($ Szefer et al., 1998). $\mathrm{AF}$ is calculated with metal surface concentration and concentration at a depth which enables differentiation between geogenic and anthropogenic input of heavy metals, the results of which would indicate the extent of anthropogenic influence on metal deposition.

For determination of trace metals in sediments, the sediments were sieved using $230 \mu$ and sediment sample was acid digested (Agemian and Chau, 1976; Voutsinou-Taliadouri, 1995). Trace metals were

Table 1: Core details

\begin{tabular}{|c|c|c|c|c|c|}
\hline Core & Latitude $(\mathrm{N})$ & Longitude (E) & Water depth in $\mathrm{m}$ & Core retrieval depth in $\mathrm{cm}$ & $\begin{array}{l}\text { Number of } \\
\text { subsamples }\end{array}$ \\
\hline 1-Aquafarm & $13^{\circ} 21.419^{\prime}$ & $80^{\circ} 19.923^{\prime}$ & 0.77 & 40.0 & 15 \\
\hline 2-Industrial discharge & $13^{\circ} 13.413^{\prime}$ & $80^{\circ} 19.139^{\prime}$ & 0.16 & 42.5 & 16 \\
\hline 3-Pulicat lagoon & $13^{\circ} 24.411^{\prime}$ & $80^{\circ} 19.505^{\prime}$ & 0.9 & 40.0 & 15 \\
\hline 4-Ennore Sea & $13^{\circ} 14^{\prime} 5^{\prime \prime} .04$ & $80^{\circ} 20^{\prime} 39^{\prime \prime} .33$ & 6.8 & 20.0 & 8 \\
\hline
\end{tabular}


determined by digestion with $\mathrm{HF}, \mathrm{HNO}_{3}$ and $\mathrm{H}_{2} \mathrm{SO}_{4}$ in a sealed Teflon vessel (Teflon bomb) using a hot plate. The digested samples were filtered with Whatman Grade "A" filter paper and the filtrate was analyzed for $\mathrm{Cd}, \mathrm{Cr}, \mathrm{Cu}, \mathrm{Pb}$ and $\mathrm{Zn}$ in Optima emission spectrophotometer Optima 2100 Dy. To check the precision of the equipment Merck's Multielement Standard Solution IV was used. Statistical analysis was carried out using SPSS (1995) to determine inter-element relationship.

\section{RESULTS AND DISCUSSION}

Temperature, salinity and DO of surface water were measured using a probe on site at the time of sampling (TableШ). The water column above core 1 recorded maximum DO of $5.4 \mathrm{mg} / \mathrm{L}$ was when compared to the other locations. The DO concentration in Ennore ranges from 1 to $6 \mathrm{mg} / \mathrm{L}$ (Kalaivani, 2007). This region receives only nutrient rich waters and there is no other source of pollutants capable of reducing the dissolved oxygen content of water. $0.7 \mathrm{mg} / \mathrm{L}$ the minimum dissolved oxygen content was observed in core 2 . This location is characterized with high sludge content and the nature of sediments itself is blackish and gooey. DOD (2001) report showed that Ennore Creek is contaminated by sewage released from Buckingham Canal with nil to low DO and values of other elements were more or less within limits. This core location also has minimum

Table 2: Surface water quality

\begin{tabular}{lccc}
\hline Core & Temperature $\left({ }^{\circ} \mathrm{C}\right)$ & Salinity $(\mathrm{ppt})$ & $\mathrm{DO}(\mathrm{mg} / \mathrm{L})$ \\
\hline 1 & 28.5 & 28.6 & 5.4 \\
2 & 29.0 & 27.2 & 0.7 \\
3 & 30.6 & 30.6 & 4.7 \\
4 & - & - & - \\
\hline
\end{tabular}

salinity value. Maximum salinity value of $30.6 \mathrm{ppt}$ was recorded in core 3 . For the sea core no surface water quality no data was obtained.

\section{Grain size}

Grain size analysis was carried out only for the surface sediments in each core. GRADSTAT analysis shows that all the core sediments are sandy in nature. Table 3 gives the detailed description of the sediments. The maximum $\mathrm{d}_{50}$ value of $408.3 \mu \mathrm{m}$ was observed in core 2 and the minimum $d_{50}$ value of $293.5 \mu \mathrm{m}$ was observed in core 3 . Fig. 2 shows the variations in statistics of grain size. Since trace metal concentrations usually increase with decreasing grain size of sediments, compensation for grain size differences is one of the most important normalization techniques for the detection and quantification of anomalous metal concentrations (Angelidis and Aloupi, 1997). Therefore, the coarser material in the sediments plays the role of the "diluent" affecting the total (bulk) metal concentration. In the present study, this was overcome by sieving the sediments and using only the fine grained sediments for estimation of the trace metals. Ennore sediments fall under the textural group sand. (Jayapraksh, 2002).

\section{Sediment composition}

Sediment composition was determined for all subsamples and the results are shown in Fig. 3. Sand was dominating except in core 3 wherein silt is present at slightly higher levels than sand. In core 1, the top 5 $\mathrm{cm}$ is composed of $40-45 \%$ sand and silt whereas clay was present only at about $14-15 \%$. Below $5 \mathrm{~cm}$ depth, there was a variation in trend such that sand was present at higher percent ranging from 55 to 90 , silt

Table 3: Description of sediments

\begin{tabular}{lllcc}
\hline Core & $\mathrm{d}_{50 \mu \mathrm{m}}$ & Description & Sorting & Skewness \\
\hline 1 & 353.3 & Medium sand & Poorly sorted & Fine Skewed \\
2 & 408.3 & Medium sand & Poorly sorted & Symmetrical \\
3 & 293.5 & Medium sand & Poorly sorted & Mesokurtic \\
4 & 315.0 & Medium sand & Poorly sorted & Coarse Skewed \\
\hline
\end{tabular}

Table 4: $\mathrm{I}_{\text {geo }}$ classification and AF for core samples of Ennore

\begin{tabular}{lcccccccccc}
\hline & & \multicolumn{3}{c}{$\mathrm{I}_{\text {geo }}$ Class } & & \multicolumn{3}{c}{$\mathrm{AF}$} & $\mathrm{Cu}$ & $\mathrm{Pb}$ \\
\hline Core 1 & $\mathrm{Cd}$ & $\mathrm{Cr}$ & $\mathrm{Cu}$ & $\mathrm{Pb}$ & $\mathrm{Zn}$ & $\mathrm{Cd}$ & $\mathrm{Cr}$ & 1.05 & 1.33 \\
Core 2 & 0 & 3 & 5 & 3 & 3 & 0 & 2.03 & 1.21 \\
Core 3 & 0 & 6 & 3 & 5 & 4 & 0 & 1.03 & 0.92 & 0.55 \\
Core 4 & 0 & 1 & 1 & 1 & 1 & 0 & 1.03 & 0.3 & 1.25 \\
\hline
\end{tabular}



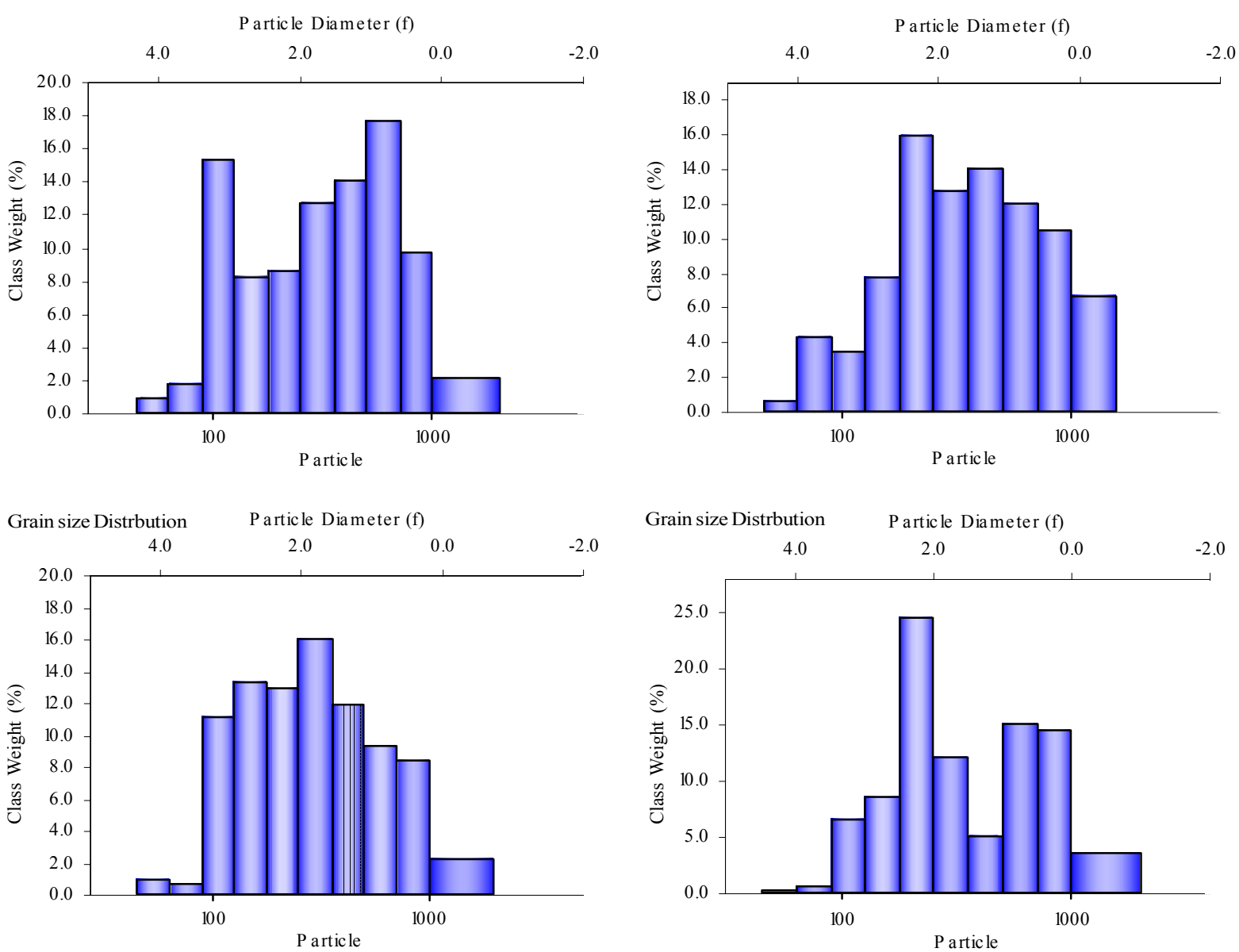

Fig. 2: Grain size variations

content dropped from 40 to $45 \%$ to $5-30 \%$ and clay content also reduced to $1-10 \%$. This suggested that the recent deposition of sediments is more of a silty sand nature rather than sandy. Core 2 as mentioned earlier shows higher silt content (45-66\%). The clay content was comparatively low and was $14-30 \%$. Sand content was higher than clay, but lesser than silt. Cores 3 and 4 were similar in their distribution of sediment composition viz. a total sand domination and clay and silt content present at lower fractions. But in core 3 sand was present at much higher fraction (89-94\%) whereas in core 4 sand was present only at 70-80\%. Silt and clay in core 3 was present at very low levels compared to the other cores. Large amounts of trace metals are bound in the fine-grained fraction $(<63 \mathrm{~mm})$ of the sediment, mainly because of its high surface area-to-grain size ratio and humic substance content (Horowitz and Elrick, 1987; Moore et al., 1989). Results from regression analysis (Table 12) showed that the metals correlated positively with clay. The metals in this fine- grained fraction are more likely to be biologically available than those in the bulk sediments (Bryan and Langston, 1992; Everaart and Fischer, 1992). Core 2 had high sand and clay content and it is this core that shows a comparatively higher concentration of trace metals.

\section{$p H$}

The accumulation of certain trace metals in sediments is directly or indirectly controlled by redox conditions through either a change in redox state (e.g., Re and $U$ ) and/or speciation (e.g., Mo). Other metals (e.g., Cd) have a single stable valence in aqueous solution but can be precipitated in the presence of dissolved sulfide (McKay, 2007). The down core variations in $\mathrm{pH}$ are shown in Fig. 4. The unevenness 
B. R. R. Seshan et al.
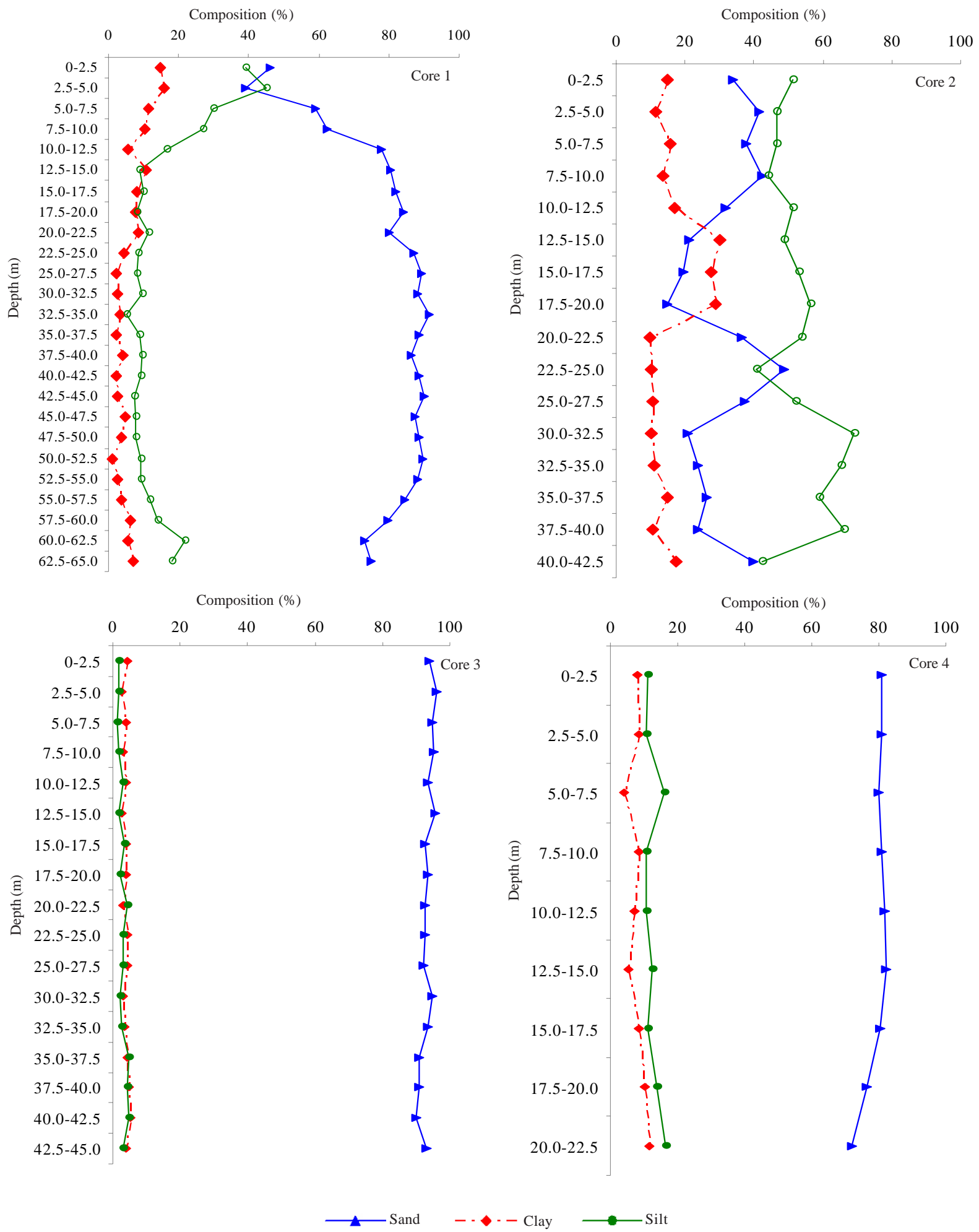

Fig. 3 Sediment composition of Ennore 


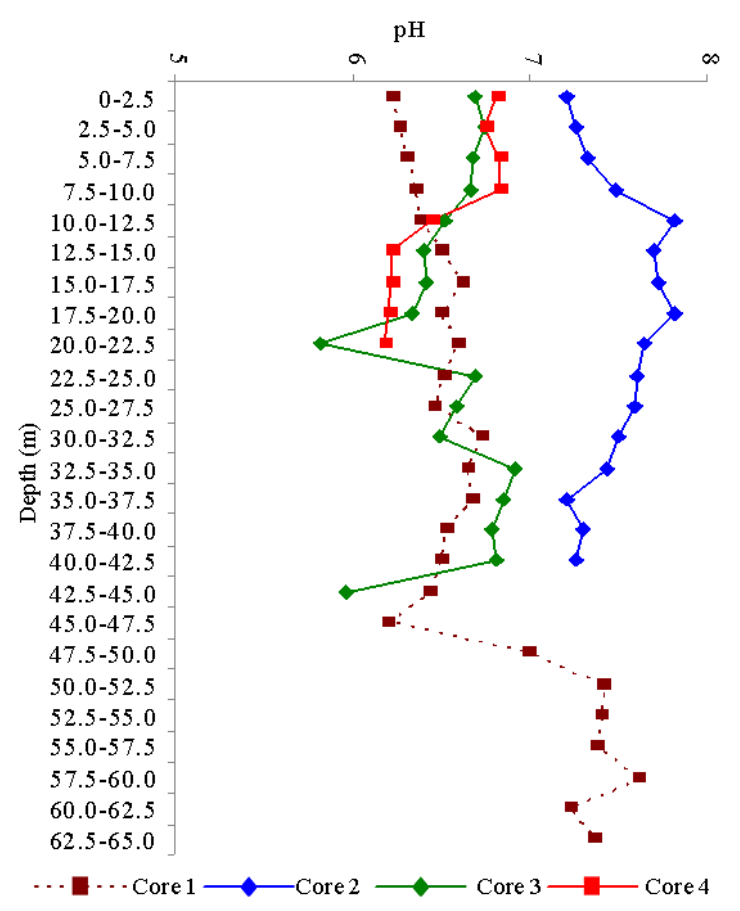

Fig. 4: Down core variations in sediment $\mathrm{pH}$

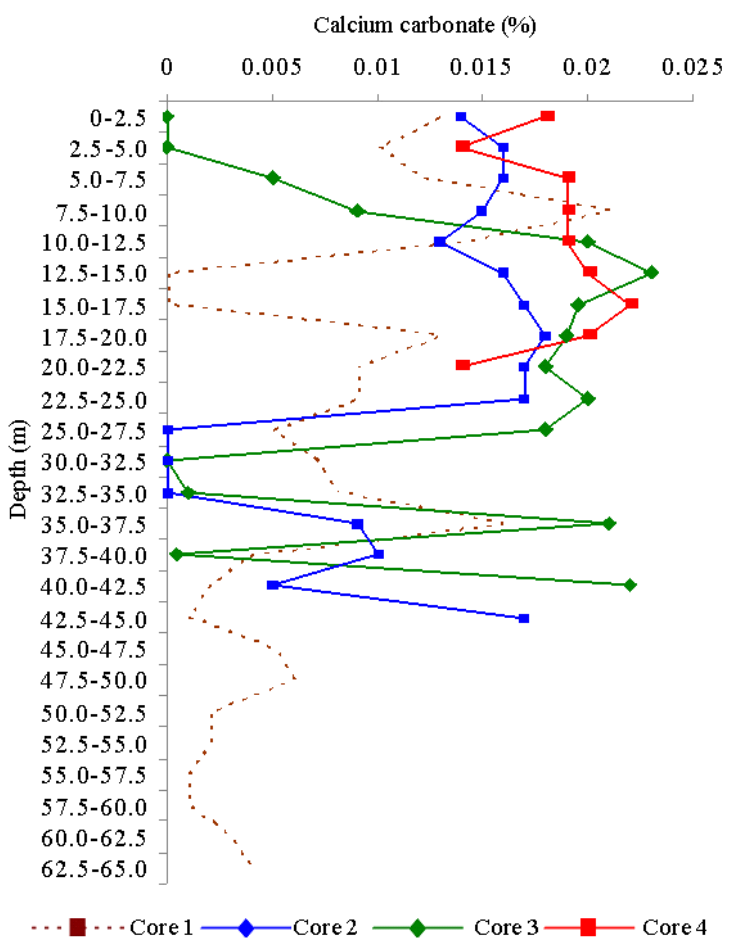

Fig. 6: Variations in calcium carbonate

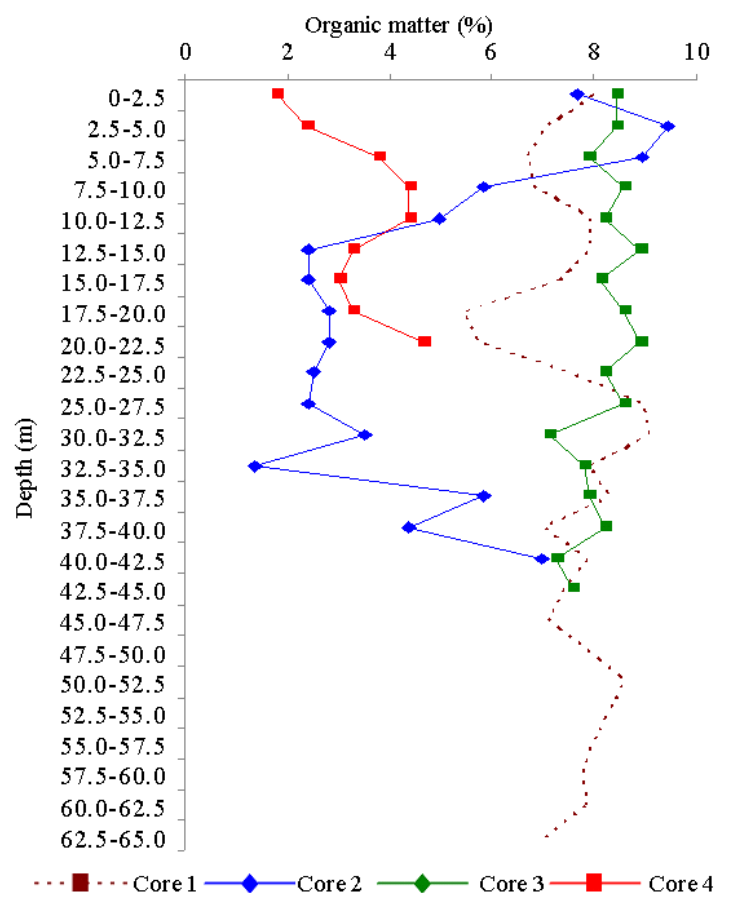

Fig. 5: Vertical profile of organic matter

in the length observed here is due to apparent variations in the core retrieval depth. $\mathrm{pH}$ for all the subsamples in the core lie in the range of slightly basic to neutral to slightly acidic. $\mathrm{pH}$ in core 1 was around 6.2-6.9 starting from surface subsample till a depth of $50 \mathrm{~cm}$, but from $50 \mathrm{~cm}$ till $65 \mathrm{~cm}$ there was an increase in the $\mathrm{pH}$ (7.27.6). Highest $\mathrm{pH}$ viz. basic nature was observed in core 2 , the reason may be the discharges from the industries are of basic nature. Cores 3 and 4 showed the least viz. a slightly acidic nature and this can be attributed to the natural state of sediments. On a closer observation in core 4 the top $10 \mathrm{~cm}$ showed $\mathrm{pH}$ values closer to neutral whereas the bottom sediments from a depth of $10 \mathrm{~cm}$ till $22.5 \mathrm{~cm}$ the $\mathrm{pH}$ values was at the range of 6.1 6.4. This indicated that only the recent sediment deposits have a $\mathrm{pH}$ value of about 6.7-6.8 and if this trend continues, they will become neutral in nature with time.

\section{Organic matter}

Once the metals are released to the environment, they are transferred to the sediments through adsorption onto suspended matter and subsequent sedimentation (Hart, 1982). The adsorption and 
sedimentation processes of metals mainly depend on the composition including grain size, carbonate content, level of organic matter, Fe-Mn oxyhydroxides, etc. (Jonathan et al., 2003). Decomposition of organic material produces organic ligands that may extract metals from the sediments which can effectively mobilize metals by increasing their concentration in the water (Fergusson 1990; Taulis 2005). Fig. 5 shows the depth variations in organic matter. Highest percentage of organic matter $(9.4 \%)$ was recorded in core 2 at a depth of $5 \mathrm{~cm}$. Clays have high specific surface area and can directly trap heavy metals, but they also may act as a substrate for organic matter flocculation (Keil et al., 1994) that in turn adsorbs metals. It is core 2 that relatively had a higher concentration of trace metals. The source for organic matter within the canal is high sedimentation rates and supply from river runoff(Muthumanickam, 2003). In core 1, the organic matter content varied from 7-9\%. Overall higher organic matter was observed in core 3 at $8-9 \%$, the source being natural organic matter production rather than influence from other terrigenous sources. Organic matter content of about 1-5\% was observed in core 4 with higher concentration in the bottom sediments and lower concentrations at the surface sediments. Tam and Wong, (2000) suggested that the concentrations of organic matter in the fine-grained fraction of the sediment were often higher than that in the sand sized fraction.

\section{Calcium carbonate}

Vertical distribution of calcium carbonate is shown in Fig. 6. Calcium carbonate in all the four core samples indicated very low values ranging from $0-0.025 \%$. Surface sediments (top $5 \mathrm{~cm}$ ) of core 2 showed a total absence of calcium carbonate due to heavy sludge loading. In cores 1, 3 and 4 the source for calcium carbonate was related to the shell fragments present in the sediments. Core 1 showed calcium carbonate of 0.001 to $0.021 \%$. At depths of $12-15 \mathrm{~cm}$, the calcium carbonate content dropped to $0 \%$. Similarly, in core 3 the calcium carbonate content dropped to $0 \%$ between 25 to $35 \mathrm{~cm}$. In core 2, between 12 to $25 \mathrm{~cm}$ calcium carbonate content of 0.02 to $0.018 \%$ was observed. Cores 2 and 3 between $25-35 \mathrm{~cm}$ showed a total absence of calcium carbonate. Core 4 , calcium carbonate was present at 0.02 to $0.019 \%$. In all the cores, below a depth of $5 \mathrm{~cm}$ the increase in calcium carbonate is due to reprecipitation and increase in alkalinity generated by sulphate reduction (Gaillard et al., 1989).

\section{Down core profiles of acid leachable trace metals}

Sediments represent one of the ultimate sinks for heavy metal discharge into the environment. A variety of processes lead to the association of heavy metals with solid phases, such as direct adsorption by finegrained inorganic particles of clays, adsorption of hydrous ferric and manganic oxides which may in turn be associated with clays, adsorption on, or complexation with natural organic substances which may also be associated with inorganic particles, and direct precipitation as new solid phases (Gibbs, 1977). Fig. 7 shows the down core variations in the concentrations of acid leachable trace metals. Elemental sequence (ES) of the trace metal is in the order of $\mathrm{Zn}$ $(0.6-3.7 \mathrm{ppm})>\mathrm{Cu}(0.3-7 \mathrm{ppm})>\mathrm{Cr}(0.2-1.2 \mathrm{ppm})>\mathrm{Pb}$ (0.031-0.1 ppm) $>\mathrm{Cd}(0-0.04 \mathrm{ppm})$.

Throughout the vertical profiles of cores 1, 3 and 4 $\mathrm{Cd}$ was totally absent. Cd was present in the top $7.5 \mathrm{~cm}$ at concentration ranging between 0.004 to $0.023 \mathrm{ppm}$ in core 2 . In all the other subsamples Cd is absent. All the cores collected for this study are within the canal and does not extend into the Ennore port area where there is higher possibility of $\mathrm{Cd}$ contamination from corrosion resistance paints. Hence the total absence or negligible concentration of $\mathrm{Cd}$ in the core samples. $\mathrm{Cr}$ behaviour in the core 1 was more or less uniform with its concentration varying at 0.2 to $0.8 \mathrm{ppm}$. In core 2 till top $10 \mathrm{~cm} \mathrm{Cu}$ was present at greater concentration beyond a depth of $10 \mathrm{~cm} \mathrm{Cr}$ dominates. Core 3 being the reference site for this study showed a lower concentration of all the trace metals throughout the core except $\mathrm{Cu}$ at depth of $35 \mathrm{~cm}$ which occurred at a concentration of $7.7 \mathrm{ppm}$. Cr again in core 4 showed a uniform trend in the vertical profile. At a depth of 15 $\mathrm{cm}, \mathrm{Cu}$ concentration shooted upto $1 \mathrm{ppm}$ whereas at the same depth $\mathrm{Cr}$ and $\mathrm{Zn}$ concentration dropped to 0.3 and 0.4 ppm, respectively. Higher concentration of $\mathrm{Cu}$ at the surface sediments and bottom sediments (1.3 - $1.7 \mathrm{ppm})$ and lower concentrations in middle subsamples (0.3-1.0 ppm) was observed for core 1. A detailed study is needed to explain the recent but uniform increase in the concentrations of $\mathrm{Cu}$ over the years. In core 2, $\mathrm{Cu}$ behaves in a manner similar to that of $\mathrm{Cr}$ but a depth of 37.5 to $40.0 \mathrm{~cm}$ its concentration raised to about $2.5 \mathrm{ppm}$ the highest concentration of $\mathrm{Cu}$ recorded throughout core 2 . Core 3 , although being 
Int. J. Environ. Sci. Tech., 7 (2), 291-306, Spring 2010
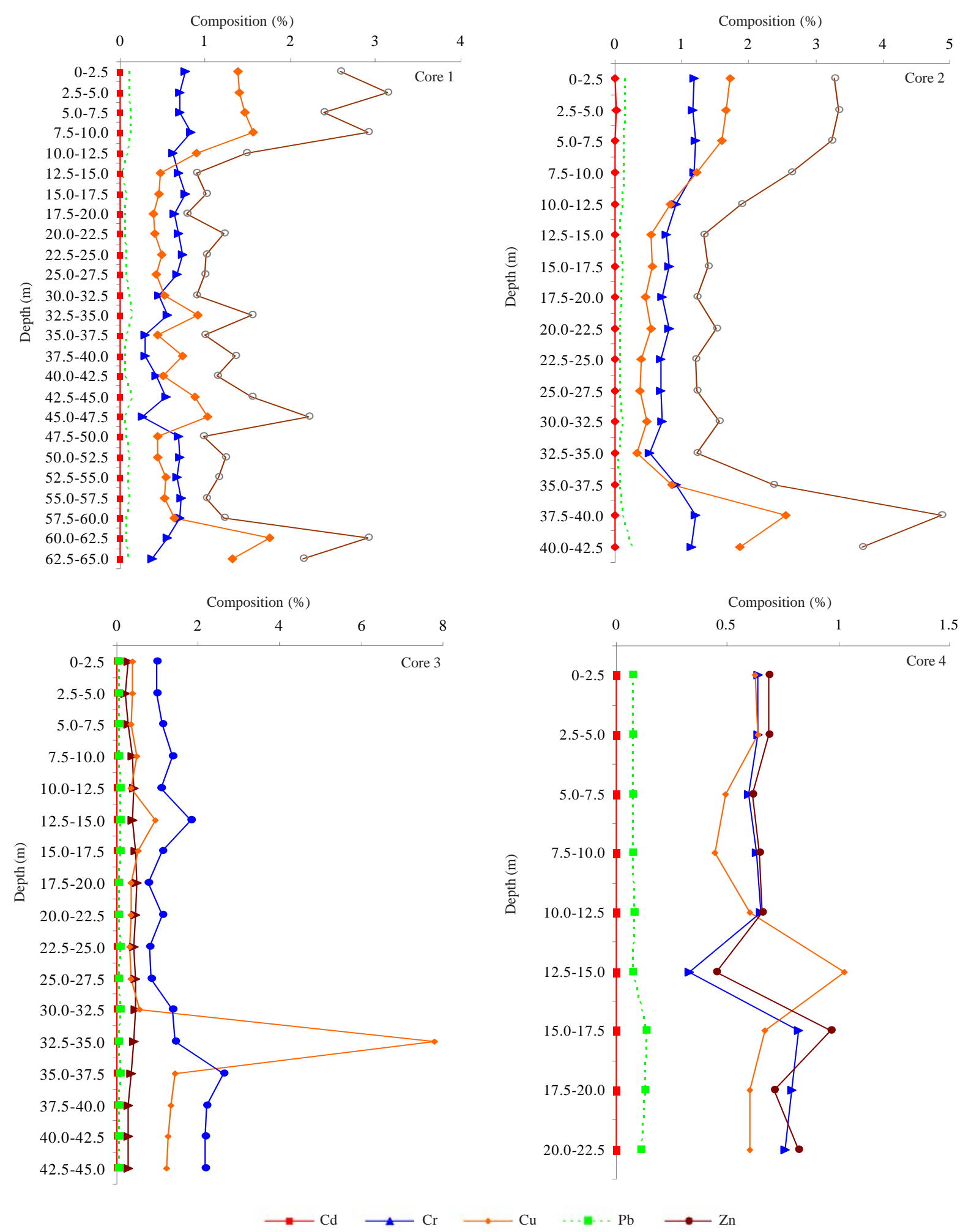

Fig. 7: Down core profile of acid leachable trace metals 
reference site, showed a $\mathrm{Cu}$ concentration of $7.7 \mathrm{ppm}$ at depth of $35 \mathrm{~cm}$. This is the highest recorded trace metal concentration. Dating of the core would provide a vital indication of the presence of $\mathrm{Cu}$ at such a high concentration, but dating was beyond the scope of this study. $\mathrm{Pb}$ in core 1 did not show down core variation and was present at very low concentrations $(0.04$ to $0.1 \mathrm{ppm})$. In core $2, \mathrm{~Pb}$ concentration varies from 0.046 to $0.254 \mathrm{ppm}$. Core 3 showed a $\mathrm{Pb}$ concentration ranging from 0.039 to $0.076 \mathrm{ppm}$. $\mathrm{Pb}$ was present at a concentration of 0.4 to $1 \mathrm{ppm}$ in core 4 . Core 4 showed a slightly higher concentration of $\mathrm{Pb}$ due to the operation of marine fleet in the Bay of Bengal and greater chances of petrol and oil spillages which contain $\mathrm{Pb}$ as additive whereas within Ennore $\mathrm{Pb}$ concentration is lower owing to the fact that majority of the fishing activity takes place in tradition catamaran only a few people make use of engine boat for fishing.

The top $12 \mathrm{~cm}$ showed a $\mathrm{Zn}$ concentration of about 1.5-3 ppm. Below this depth, i.e. from $15-65 \mathrm{~cm}$ its concentration varied at about $1 \mathrm{ppm}$ except at a depth of $60 \mathrm{~cm}$ where the concentrations shooted upto $2 \mathrm{ppm}$, dating of the sediments would give a clue for this sudden increase in its concentration. Otherwise it can be said it is the surface sediments that have higher concentration of $\mathrm{Zn}$. Overall $\mathrm{Zn}$ is the highest occurring trace metal in cores 1 and 2 . $\mathrm{Zn}$ has accumulated at higher concentrations at the surface sediments when compared to the bottom sediments. Even in Pulicat it is $\mathrm{Zn}$ that is seen to occur at higher concentration although not as high as observed in cores 1 and 2 . In Core 3 the $\mathrm{Zn}$ concentration is 0.8 to $2 \mathrm{ppm}$. This is indicative that $\mathrm{Zn}$ has a higher background value compared to the other metals within the study area. On a closer observation it can be reported that $\mathrm{Zn}$ was present at a higher concentration even in Core 4, proving that $\mathrm{Zn}$ is naturally occurring at a higher concentration. Metal absorption capacity is in the order of sand $<$ silt $<$ clay, due to increases in surface area, minerals and organic matter as particle size decreased from sand to clay (Tam and Wong, 2000). Core 2 has higher content of silt and clay compared to sand and this core has higher concentration of heavy metal too. Pulicat being the reference for this study showed that occurrence of trace metal was found to be at very low concentrations which vouched for the fact that Pulicat is pristine and currently not polluted and contaminated from anthropogenic activities. Results of trace metal analysis from core 4 showed that this area is not under the impact of human activities. Pollutants from Ennore have not dispersed into the sea and this is evident from core 4 that was collected at about $2 \mathrm{~km}$ into the Bay of Bengal from the coast.

Results from Regression analysis (Table 12) showed that $\mathrm{Cu}$ and $\mathrm{Zn}$ correlated positively with $\mathrm{Zn}$ in core 1 . $\mathrm{Cu}$ was found to correlate positively with $\mathrm{Zn}$. Organic matter in core 2 is positively correlated with all the heavy metals. This pointed out that deposition is near source and it has not yet moved to the fine clay fraction. Core 3 not much correlation is observed due to the low clay content and very high sand content $(89-96 \%$ sand). In core 4, clay correlated positively with $\mathrm{Cr}, \mathrm{Pb}$ and $\mathrm{Zn}(\mathrm{R}=0.71, \mathrm{R}=0.65$ and $\mathrm{R}=0.64$, respectively) showing heavy metal adhere to fine grained fraction. $\mathrm{Cr}$ and $\mathrm{Pb}, \mathrm{Cr}$ and $\mathrm{Zn}, \mathrm{Pb}$ and $\mathrm{Zn}$ are positively correlated indicating they are from the same anthropogenic source.

\section{Geoaccumalation index}

The geoaccumulation index $\left(\mathrm{I}_{\text {geo }}\right)$ introduced by Muller (1979) was used to assess metal pollution in sediments of Ennore. $\mathrm{I}_{\text {geo }}$ is expressed as follows:

$$
\mathrm{I}_{\text {geo }}=\log _{2}\left(\mathrm{C}_{\mathrm{n}} / 1.5 \times \mathrm{B}_{\mathrm{n}}\right)
$$

Where,

$\mathrm{C}_{\mathrm{n}}$ - measured concentration of heavy metal in the sediment,

$\mathrm{B}_{\mathrm{n}}$ - geochemical background value in average shale (Turekian and Wedepohl 1961) of element n,

1.5 is the background matrix correction in factor due to lithogenic effects.

Geoaccumalation index classes to assess sediment quality

$<0$ Uncontaminated

1 Uncontaminated to moderately contaminated

2 Moderately contaminated

3 Moderately to highly contaminated

4 Highly contaminated

5 Highly to very highly contaminated

6 Very highly contaminated

$I_{\text {geo }}$ calculation was carried out only for the surface sediment in each core. The calculated values for Ennore and its surrounding marine environment are given in Table 4.

Ennore is uncontaminated with respect to $\mathrm{Cd}$. $\mathrm{Cr}$ in core 2 falls under class 6 indicating very high contamination. Core 3 being reference for this study falls under the category 1 . Uncontamination or moderate contamination was observed in Ennore Sea. 
Int. J. Environ. Sci. Tech., 7 (2), 291-306, Spring 2010

Table 5: Heavy metal enrichment factor in core sediments of Ennore

\begin{tabular}{|c|c|c|c|c|c|c|}
\hline Station & DEPTH $(\mathrm{cm})$ & $\mathrm{EF}(\mathrm{Cd})$ & $\mathrm{EF}(\mathrm{Cr})$ & $\mathrm{EF}(\mathrm{Cu})$ & $\mathrm{EF}(\mathrm{Pb})$ & $\mathrm{EF}(\mathrm{Zn})$ \\
\hline \multirow[t]{26}{*}{ Core 1} & $0-2.5$ & 0 & 1.51 & 4.77 & 0.89 & 4.88 \\
\hline & $2.5-5.0$ & 0 & 1.51 & 5.28 & 0.93 & 6.48 \\
\hline & $5.0-7.5$ & 0 & 1.41 & 5.09 & 0.97 & 4.56 \\
\hline & $7.5-10.0$ & 0 & 1.54 & 5.07 & 0.92 & 5.15 \\
\hline & $10.0-12.5$ & 0 & 3.25 & 8.24 & 1.95 & 7.40 \\
\hline & $12.5-15.0$ & 0 & 11.67 & 13.87 & 1.85 & 14.60 \\
\hline & $15.0-17.5$ & 0 & 2.02 & 2.10 & 0.74 & 2.52 \\
\hline & $17.5-20.0$ & 0 & 3.7 & 3.99 & 1.19 & 4.35 \\
\hline & $20.0-22.5$ & 0 & 1.44 & 1.51 & 0.53 & 2.45 \\
\hline & $22.5-25.0$ & 0 & 1.43 & 1.67 & 0.53 & 1.88 \\
\hline & $25.0-27.5$ & 0 & 1.35 & 1.50 & 0.56 & 1.91 \\
\hline & $27.5-30.0$ & 0 & 2.58 & 5.19 & 2.39 & 4.86 \\
\hline & $30.0-32.5$ & 0 & 1.36 & 3.88 & 1.40 & 3.64 \\
\hline & $32.5-35.0$ & 0 & 1.34 & 3.36 & 1.15 & 4.25 \\
\hline & $35.0-37.5$ & 0 & 1.37 & 6.04 & 1.09 & 6.06 \\
\hline & $37.5-40.0$ & 0 & 1.42 & 2.92 & 0.76 & 3.60 \\
\hline & $40.0-42.5$ & 0 & 1.35 & 3.85 & 1.39 & 3.68 \\
\hline & $42.5-45.0$ & 0 & 1.35 & 9.04 & 1.09 & 10.61 \\
\hline & $45.0-47.5$ & 0 & 1.35 & 1.52 & 0.56 & 1.82 \\
\hline & $47.5-50.0$ & 0 & 1.36 & 1.34 & 0.75 & 2.06 \\
\hline & $50.0-52.5$ & 0 & 1.23 & 1.92 & 0.74 & 2.23 \\
\hline & $52.5-55.0$ & 0 & 1.36 & 1.78 & 0.83 & 1.87 \\
\hline & $55.0-57.5$ & 0 & 1.39 & 2.34 & 0.61 & 2.44 \\
\hline & $57.5-60.0$ & 0 & 1.46 & 7.10 & 0.69 & 6.43 \\
\hline & $60.0-62.5$ & 0 & 1.29 & 7.83 & 1.16 & 7.00 \\
\hline & $62.5-65.0$ & 0 & 1.29 & 7.81 & 1.10 & 7.00 \\
\hline \multirow[t]{16}{*}{ Core 2} & $0-2.5$ & 2.90 & 2.84 & 7.16 & 1.52 & 7.50 \\
\hline & $2.5-5.0$ & 15.02 & 2.52 & 6.28 & 1.38 & 6.87 \\
\hline & $5.0-7.5$ & 5.73 & 2.57 & 5.85 & 1.19 & 6.52 \\
\hline & $7.5-10.0$ & 0 & 3.40 & 6.12 & 1.58 & 7.21 \\
\hline & $10.0-12.5$ & 0 & 2.05 & 3.16 & 1.10 & 3.96 \\
\hline & $12.5-15.0$ & 0 & 1.71 & 2.06 & 0.51 & 2.79 \\
\hline & $15.0-17.5$ & 0 & 1.72 & 2.04 & 0.92 & 2.80 \\
\hline & $17.5-20.0$ & 0 & 1.66 & 1.85 & 0.78 & 2.70 \\
\hline & $20.0-22.5$ & 0 & 1.82 & 2.12 & 0.73 & 3.24 \\
\hline & $22.5-25.0$ & 0 & 1.61 & 1.57 & 0.60 & 2.65 \\
\hline & $25.0-27.5$ & 0 & 1.55 & 1.45 & 0.57 & 2.58 \\
\hline & $27.5-30.0$ & 0 & 1.54 & 1.76 & 0.92 & 3.15 \\
\hline & $30.0-32.5$ & 0 & 0.96 & 1.03 & 0.38 & 2.12 \\
\hline & $32.5-35.0$ & 0 & 2.19 & 3.50 & 0.75 & 5.36 \\
\hline & $35.0-37.5$ & 0 & 3.22 & 11.81 & 1.33 & 12.36 \\
\hline & $37.5-40.0$ & 0 & 2.65 & 7.49 & 2.66 & 8.16 \\
\hline \multirow[t]{18}{*}{ Core 3} & $0-2.5$ & 0 & 1.83 & 4.42 & 1.18 & 6.26 \\
\hline & $2.5-5.0$ & 0 & 1.46 & 4.40 & 1.19 & 6.28 \\
\hline & $5.0-7.5$ & 0 & 1.22 & 2.48 & 0.87 & 4.59 \\
\hline & $7.5-10.0$ & 0 & 1.31 & 2.96 & 0.70 & 4.45 \\
\hline & $10.0-12.5$ & 0 & 1.28 & 1.97 & 0.81 & 3.22 \\
\hline & $12.5-15.0$ & 0 & 2.32 & 10.11 & 2.17 & 10.46 \\
\hline & $15.0-17.5$ & 0 & 1.23 & 2.50 & 0.82 & 2.87 \\
\hline & $17.5-20.0$ & 0 & 1.18 & 1.45 & 0.49 & 1.77 \\
\hline & $20.0-22.5$ & 0 & 1.21 & 1.55 & 0.48 & 2.79 \\
\hline & $22.5-25.0$ & 0 & 1.16 & 1.48 & 0.66 & 2.04 \\
\hline & $25.0-27.5$ & 0 & 1.17 & 1.56 & 0.56 & 2.09 \\
\hline & $27.5-30.0$ & 0 & 1.18 & 2.47 & 0.87 & 3.25 \\
\hline & $30.0-32.5$ & 0 & 3.10 & 97.71 & 1.43 & 9.82 \\
\hline & $32.5-35.0$ & 0 & 1.97 & 14.30 & 1.54 & 14.51 \\
\hline & $35.0-37.5$ & 0 & 3.18 & 27.33 & 1.81 & 24.53 \\
\hline & $37.5-40.0$ & 0 & 3.13 & 25.95 & 1.70 & 24.42 \\
\hline & $40.0-42.5$ & 0 & 3.12 & 24.99 & 1.68 & 24.27 \\
\hline & $42.5-45.0$ & 0 & 3.11 & 25.29 & 1.65 & 24.41 \\
\hline \multirow[t]{9}{*}{ Core 4} & $0-2.5$ & 0 & 1.49 & 2.55 & 0.79 & 1.53 \\
\hline & $2.5-5.0$ & 0 & 1.51 & 2.62 & 0.79 & 1.54 \\
\hline & $5.0-7.5$ & 0 & 1.50 & 2.14 & 0.80 & 1.46 \\
\hline & $7.5-10.0$ & 0 & 1.49 & 1.82 & 0.76 & 1.44 \\
\hline & $10.0-12.5$ & 0 & 1.51 & 2.43 & 0.82 & 1.45 \\
\hline & $12.5-15.0$ & 0 & 1.51 & 8.15 & 1.44 & 1.95 \\
\hline & $15.0-17.5$ & 0 & 2.01 & 2.83 & 1.50 & 2.24 \\
\hline & $17.5-20.0$ & 0 & 2.05 & 2.71 & 1.50 & 1.75 \\
\hline & $20.0-22.5$ & 0 & 1.98 & 2.70 & 1.31 & 2.02 \\
\hline
\end{tabular}


At all, it is core 2 that showed high contamination for all the heavy metals.

\section{Anthropogenic factor (AF)}

In order to evaluate the data in detail, the anthropogenic factors of elements in the cores were calculated according to the following formula,

$\mathrm{AF}=\mathrm{C}_{\mathrm{s}} / \mathrm{C}_{\mathrm{d}}$ (Szefer et al., 1998)

Where, $\mathrm{C}_{\mathrm{s}}$ and $\mathrm{C}_{\mathrm{d}}$ refer to the concentrations of the elements in the surface sediments and at depth in sediment column. According to Ruiz-Ferna'ndez et al., (2001), if AF is $>1$ for a particular metal, it means contamination exists; otherwise, if $\mathrm{AF}$ is $\leq 1$, there is no metal enrichment of anthropogenic origin. AF for the cores collected in Ennore is tabulated in Table 4.

$\mathrm{Cd}$ had no anthropogenic enrichment since Cd was absent. Cr has metal enrichment in all cores except in core 4 proving that pollutants have not got dispersed and deposited onto the marine sediment. $\mathrm{Cu}$ in cores 2 and 3 have no anthropogenic origin. $\mathrm{Zn}$ showed anthropogenic input in core 1 . On the whole, it was core 1 that showed higher anthropogenic input compared to the other cores.

\section{Enrichment factor (EF)}

EF was calculated to determine if levels of metals in sediments of Ennore and its surrounding marine environment were of anthropogenic origins (e.g., contamination). To identify anomalous metal

Table 6: Classification of contamination factor and contamination degree

\begin{tabular}{lll}
\hline \multicolumn{1}{c}{$\mathrm{C}_{\mathrm{f}}^{\mathrm{i}}$} & \multicolumn{1}{c}{$\mathrm{C}_{\mathrm{d}}$} & \multicolumn{1}{c}{ Status } \\
\hline $\mathrm{C}_{\mathrm{f}}^{\mathrm{i}}<1$ & $\mathrm{C}_{\mathrm{d}}<7$ & Low degree of contamination \\
$1<\mathrm{C}_{\mathrm{f}}^{\mathrm{i}}<3$ & $7<\mathrm{C}_{\mathrm{d}}<14$ & Moderate degree of contamination \\
$3<\mathrm{C}_{\mathrm{f}}^{\mathrm{i}}<6$ & $7<\mathrm{C}_{\mathrm{d}}<28$ & Considerable degree of contaminatio \\
$\mathrm{C}_{\mathrm{f}}^{\mathrm{i}}>6$ & $\mathrm{C}_{\mathrm{d}}>28$ & Very degree of contamination \\
\hline
\end{tabular}

Table 7: Contamination factor and contamination degree

\begin{tabular}{lllll}
\hline & $\mathrm{C}_{\mathrm{f}}^{\mathrm{i}}$ & $\mathrm{C}_{\mathrm{f}}^{\mathrm{i}}$ & $\mathrm{C}_{\mathrm{f}}^{\mathrm{i}}$ & $\mathrm{C}_{\mathrm{f}}^{\mathrm{i}}$ \\
& Core 1 & Core 2 & Core 3 & Core 4 \\
\hline $\mathrm{Cd}$ & 0.00 & 0.00 & 0.00 & 0.00 \\
$\mathrm{Cr}$ & 1.63 & 2.49 & 1.00 & 1.77 \\
$\mathrm{Cu}$ & 0.74 & 0.92 & 1.00 & 0.59 \\
$\mathrm{~Pb}$ & 1.54 & 2.06 & 1.00 & 1.85 \\
$\mathrm{Zn}$ & 1.10 & 1.59 & 1.00 & 0.49 \\
& \multicolumn{5}{c}{ Conatmination degree $\mathrm{C}_{\mathrm{d}}$} \\
& \multicolumn{5}{c}{ Core 2 } & Core 3 & Core 4 \\
& Core 1 & 7.06 & 4.69 \\
& 5.01 & &
\end{tabular}

concentration, geochemical normalization of the heavy metals data to a conservative element, such as $\mathrm{Al}, \mathrm{Fe}$, and $\mathrm{Si}$ was employed. Several authors have successfully used iron to normalize heavy metals contaminants (Schiffand Weisberg, 1999; Baptista Neto et al., 2000; Mucha et al., 2003). In this study, iron was also used as a conservative tracer to differentiate natural from anthropogenic components. According to Ergin et al., (1991), the metal EF is defined as follows:

$E F=\frac{(M / F e)_{\text {sample }}}{(M / F e)_{\text {Background }}}$

EF values were interpreted as suggested by Birch (2003) where $\mathrm{EF}<1$ indicates no enrichment, $<3$ is minor; $3-5$ is moderate; $5-10$ is moderately severe; 10 25 is severe; $25-50$ is very severe; and $>50$ is extremely severe. Table 5 gives Heavy metal Enrichment Factor in core sediments of Ennore. $\mathrm{Cd}$ in all the cores showed no enrichment except in core 2 . The surface sediments showed minor, severe and moderately severe enrichment in the top $7.5 \mathrm{~cm}$, respectively indicating increase in $\mathrm{Cd}$ concentration in the recent few years due to the close proximity of this site to industrial discharges. $\mathrm{Cr}$ in cores 1 and 4 showed minor enrichment throughout the vertical profile except at a depth of $15 \mathrm{~cm}$ in core 1 which shows severe enrichment. Cores 2 and 3 have minor to moderate $\mathrm{Cr}$ enrichment. $\mathrm{Cu}$ enrichment down the cores 1,2 and 4 is highly variable with minor, moderate and moderately severe enrichment. The same holds good for 3 as well but the enrichment factor shoots upto 97.71. The raise in value is due to the higher concentration of the heavy metal recorded at a depth of about $35 \mathrm{~cm}$. Pb shows no enrichment in all the four cores. Moderate to moderately severe enrichment is observed for $\mathrm{Zn}$ in the cores collected from Ennore.

\section{Contamination factor (CF) and degree of contamination}

Hakanson (1980) had suggested a contamination factor $\left(\mathrm{C}_{\mathrm{f}}^{\mathrm{i}}\right)$ and the degree of contamination $\left(\mathrm{C}_{\mathrm{d}}\right)$ to

Table 8: Pollution load index

\begin{tabular}{lcc}
\hline Metal & Pollution load & Index \\
\hline $\mathrm{Cd}$ & 0.00 & Not polluted \\
$\mathrm{Cr}$ & 1.48 & Polluted \\
$\mathrm{Cu}$ & 1.25 & Polluted \\
$\mathrm{Pb}$ & 0.98 & Not polluted \\
$\mathrm{Zn}$ & 0.97 & Not polluted \\
\hline
\end{tabular}


Int. J. Environ. Sci. Tech., 7 (2), 291-306, Spring 2010

Table 9: Concentration of heavy metal in Ennore and its comparison with SQGs

\begin{tabular}{|c|c|c|c|c|c|c|c|}
\hline \multirow{2}{*}{$\begin{array}{l}\text { Element } \\
\mathrm{mg} / \mathrm{kg}\end{array}$} & \multicolumn{4}{|c|}{ Sampling stations } & \multirow{2}{*}{$\begin{array}{l}\text { SQG non- } \\
\text { polluted } \\
(\mathrm{mg} / \mathrm{kg})\end{array}$} & \multirow{2}{*}{$\begin{array}{l}\text { SQG moderately } \\
\text { polluted }(\mathrm{mg} / \mathrm{kg})\end{array}$} & \multirow{2}{*}{$\begin{array}{c}\text { SQG Heavily } \\
\text { Polluted } \\
(\mathrm{mg} / \mathrm{kg})\end{array}$} \\
\hline & Core 1 & Core 2 & Core 3 & Core 4 & & & \\
\hline $\mathrm{Cd}$ & 0.00 & 0.00 & 0.00 & 0.00 & - & - & - \\
\hline $\mathrm{Cu}$ & 80 & 100 & 108 & 63 & $<25$ & $25-50$ & $>50$ \\
\hline $\mathrm{Pb}$ & 9 & 10 & 5 & 9 & $<40$ & $40-60$ & $>60$ \\
\hline $\mathrm{Zn}$ & 155 & 225 & 141 & 69 & $<90$ & $90-200$ & $>200$ \\
\hline
\end{tabular}

Table 10: Sediment quality guideline and definitions used

\begin{tabular}{lc}
\hline \multicolumn{1}{c}{ Sediment guideline } & Description \\
\hline Effect range low (ERL)/ Effect range median (ERM) & Adverse effect infrequent \\
Threshold effect level (TEL)/ Probable effect level (PEL) & Adverse effect likely to occur \\
\hline
\end{tabular}

Table 11: Ecotoxicological sense according to SQGs for Ennore

\begin{tabular}{lrrrrrrrr}
\hline $\begin{array}{l}\text { Element } \\
\mathrm{mg} / \mathrm{kg}\end{array}$ & \multicolumn{9}{c}{ Sampling stations } & & TEL mg/kg & PEL mg/kg & ERL mg/kg & $\begin{array}{c}\text { ERM } \\
\mathrm{mg} / \mathrm{kg}\end{array}$ \\
\hline $\mathrm{Cd}$ & Core 1 & Core 2 & Core 3 & Core 4 & & & \\
$\mathrm{Cr}$ & 0.00 & 0.00 & 0.00 & 0.00 & 0.68 & 4.20 & 1.20 \\
$\mathrm{Cu}$ & 60 & 91 & 37 & 65 & 52.30 & 160.00 & 81.00 & 370.00 \\
$\mathrm{~Pb}$ & 80 & 100 & 108 & 63 & 18.70 & 110.00 & 34.00 & 270.00 \\
$\mathrm{Zn}$ & 9 & 10 & 5 & 9 & 30.20 & 110.00 & 46.70 & 218.00 \\
\hline
\end{tabular}

describe the contamination (Table 6) of given toxic substance given by:

$\mathrm{C}_{\mathrm{f}}^{\mathrm{i}}=\mathrm{C}_{0-1}^{\mathrm{i}} / \mathrm{C}_{\mathrm{n}}^{\mathrm{i}}$ and $\mathrm{C}_{\mathrm{d}}=\Sigma^{7}{ }_{\mathrm{i}=1} \mathrm{C}_{\mathrm{f}}^{\mathrm{i}}$

Where, $\mathrm{C}_{0-1}^{\mathrm{i}}$ is the mean content of the substance;

$\mathrm{C}^{\mathrm{i}}{ }_{\mathrm{n}}$ is the reference value for the substance.

Core samples collected from Ennore fall under the category of low to moderate contamination. Degree of contamination was low except for core 2 which showed $\mathrm{C}_{\mathrm{d}}$ 7.06 marginally falls under moderate contamination (Table 7).

Pollution load index (PLI)

Tomlinson et al. (1980) had employed a simple method based on pollution load index to assess the extent of pollution by metals in estuarine sediments. Sediment pollution load index was calculated using the equation:

$\mathrm{CF}=\mathrm{C}_{\text {metal }} / \mathrm{C}_{\text {background }}$

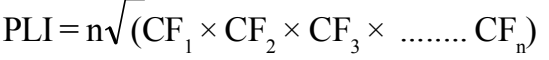

Where, $\mathrm{CF}$ is the contamination factor,

$\mathrm{C}_{\text {metal }}$ is the concentration of pollutant in sediment

$\mathrm{C}_{\text {background }}$ is the background value for the metal

$\mathrm{n}$ is the number of metals.

The PLI value $>1$ is polluted whereas $<1$ indicates no pollution.
Table 8 gives PLI calculation. Results showed that Ennore is not polluted as far as $\mathrm{Cd}, \mathrm{Zn}$ and $\mathrm{Pb}$ is considered but polluted for $\mathrm{Cr}$ and $\mathrm{Cu}$.

Assessment of sediment pollution based on sediment quality guidelines

The primary purpose of sediment quality guidelines (SQGs) are to protect aquatic biota from the harmful and toxic effects related with sediment bound contaminants and is a useful tool for evaluating potential for contaminants within sediment to induce biological effects (Spencer and Macleod, 2002). Sediments were classified as non-polluted, moderately polluted, based on SQGs of USEPA (Perin et al., 1997). According to SQGs, Cr was under the category heavily polluted in core 2 whereas in other cores it was Moderately Polluted. Ennore was seen to be heavily polluted with $\mathrm{Cu}$ whilst not polluted in case of $\mathrm{Pb}$ and Zn (Table 9).

Ecotoxicological sense of heavy metal contamination

The ecotoxicological sense of heavy metal contamination in sediments was determined using SQGs developed for marine and estuarine ecosystem (Bakan and Ozkoc, 2007). Table 11 
B. R. R. Seshan et al.

Table 12: Correlation coefficient matrix of sedimentalogical parameters and heavy metals from Ennore, Southeast coast of India $(\mathrm{P}<0.05)$

Core 1

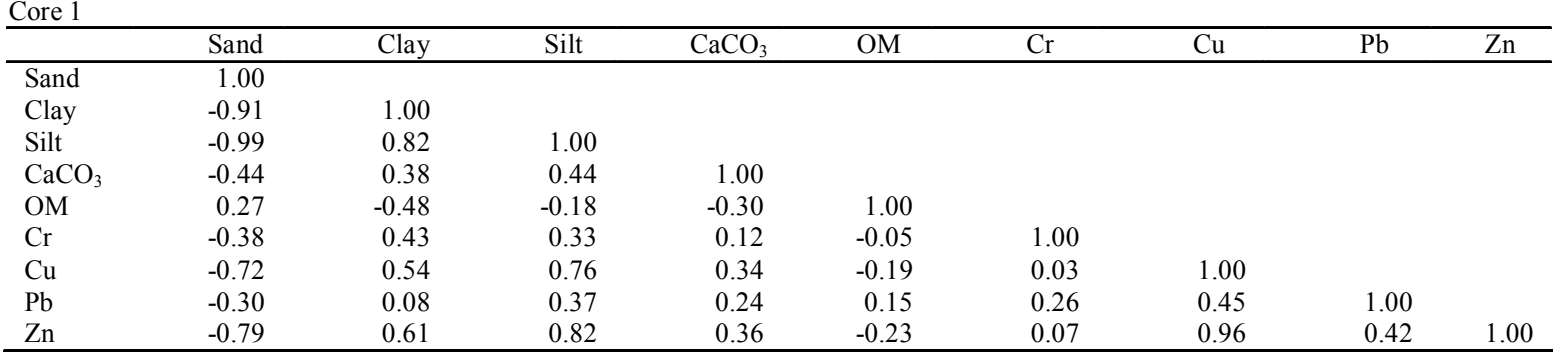

\begin{tabular}{|c|c|c|c|c|c|c|c|c|c|}
\hline Sand & 1.00 & & & & & & & & \\
\hline Silt & -0.73 & -0.17 & 1.00 & & & & & & \\
\hline $\mathrm{OM}$ & 0.45 & -0.18 & -0.38 & -0.37 & 1.00 & & & & \\
\hline $\mathrm{Cr}$ & 0.38 & -0.12 & -0.35 & -0.33 & 0.87 & 1.00 & & & \\
\hline $\mathrm{Cu}$ & 0.24 & -0.21 & -0.11 & -0.45 & 0.73 & 0.39 & 1.00 & & \\
\hline
\end{tabular}

\begin{tabular}{|c|c|c|c|c|c|c|c|c|c|}
\hline Sand & 1.00 & & & & & & & & \\
\hline Clay & -0.85 & 1.00 & & & & & & & \\
\hline Silt & -0.93 & 0.60 & 1.00 & & & & & & \\
\hline $\mathrm{CaCO}_{3}$ & 0.29 & -0.25 & -0.26 & 1.00 & & & & & \\
\hline $\mathrm{OM}$ & 0.33 & -0.39 & -0.23 & 0.50 & 1.00 & & & & \\
\hline $\mathrm{Cr}$ & 0.03 & -0.22 & 0.05 & -0.15 & 0.19 & 1.00 & & & \\
\hline $\mathrm{Cu}$ & -0.08 & 0.02 & 0.09 & -0.49 & -0.27 & 0.07 & 1.00 & & \\
\hline $\mathrm{Pb}$ & 0.28 & -0.40 & -0.20 & -0.08 & 0.03 & 0.55 & -0.12 & 1.00 & \\
\hline $\mathrm{Zn}$ & -0.50 & 0.33 & 0.52 & -0.20 & -0.43 & -0.45 & 0.23 & -0.09 & 1.00 \\
\hline
\end{tabular}

\begin{tabular}{|c|c|c|c|c|c|c|c|c|c|}
\hline Sand & 1.00 & & & & & & & & \\
\hline Clay & -0.72 & 1.00 & & & & & & & \\
\hline Silt & -0.73 & 0.05 & 1.00 & & & & & & \\
\hline $\mathrm{CaCO}_{3}$ & 0.43 & -0.38 & -0.24 & 1.00 & & & & & \\
\hline $\mathrm{OM}$ & -0.38 & 0.12 & 0.43 & -0.04 & 1.00 & & & & \\
\hline $\mathrm{Cr}$ & -0.54 & 0.71 & 0.08 & -0.05 & 0.08 & 1.00 & & & \\
\hline $\mathrm{Cu}$ & 0.23 & -0.24 & -0.09 & 0.18 & -0.28 & -0.62 & 1.00 & & \\
\hline $\mathrm{Pb}$ & -0.58 & 0.65 & 0.20 & 0.25 & 0.06 & 0.77 & -0.05 & 1.00 & \\
\hline $\mathrm{Zn}$ & -0.44 & 0.64 & 0.01 & 0.00 & -0.01 & 0.90 & -0.39 & 0.79 & 1.00 \\
\hline
\end{tabular}

outlines sediment quality guideline and definitions used. Impacts would be observed on all sediment dwelling fauna.

$\mathrm{Cr}$ and $\mathrm{Cu}$ in cores 1, 2 and 4 exceed TEL values which can lead to adverse impact on the sediment dwelling fauna (Table 11). Core 3 does not exceed the guideline thereby proving that Pulicat is uncontaminated. $\mathrm{Pb}$ and $\mathrm{Zn}$ again do not exceed the guideline concentrations.

\section{CONCLUSION}

Ennore's sandy environment (80-90\%) had pH values ranging between 5.97-7.81. High percentage of organic matter was found in core 3 (7.8 to $8.2 \%$ as compared to 1.3 to $8 \%$ ). Calcium carbonate was present at very low percentage (0-0.025). Results of trace metals concentration in the cores collected from Buckingham Canal, Ennore show considerable amount of trace metal accumulation. $\mathrm{Zn}$ is found to be the highest occurring trace metal and $\mathrm{Cd}$ was the least occurring trace metal. The distribution patterns of $\mathrm{Cd}, \mathrm{Cr}, \mathrm{Cu}, \mathrm{Pb}$ and $\mathrm{Zn}$ were controlled by the distribution of the fine-grained fraction in the sediments. $\mathrm{Cd}$ was absent in all cores and $\mathrm{Pb}$ was almost absent except in core 4 . Core 4 results 
showed that pollutants present in Ennore had not dispersed into the Bay of Bengal. Among the studied trace metals only $\mathrm{Cr}$ and $\mathrm{Cu}$ was of concern, which occasionally may be associated with adverse biological effects based on the comparison SQGs technique. This requires biological and ecological studies to elucidate the impact of $\mathrm{Cr}$ and $\mathrm{Cu}$ on the organisms of Ennore. Furthermore, with respect to the quantitative indexes, the sediments of Ennore are considered to be moderately polluted.

\section{REFERENCES}

Agemian, H.; Chau, A. S. Y., (1976). Evaluation of extraction technique for 450 the determination of metals in aquatic sediments. Analyst, 101, 761-767 (7 pages).

Angelidis, M. O.; Aloupi, M., (1997). Assessment of metal concentrations in shallow coastal sediments around Mytilene, Greece. Interm. J. Environ. Anal. Chem., 68 (2), 281-293 (13 pages).

Araujo, M. F. D.; Bernard, P. C.; VanGrieken, R. E., (1988). Heavy metal contamination in sediments from the Belgium Coast and Scheldt estuary. Mar. Pollut. Bull., 19, 269-73 (5 pages).

Bakan, G.; Ozkoc, H. B., (2007). An ecological risk assessment of the impact of heavy metals in surface sediments on biota from the mid-Black Sea coast of Turkey. Int. J. Environ. Stud., 64 (1), $45-57$ (13 pages).

Baptista Neto, J. A.; Smith, B. J.; McAllister, J. J., (2000). Heavy metal concentrations in surface sediments in a nearshore environment, Jurujuba Sound, Southeast Brazil. Environ. Pollut., 109 (1), 1-9 (9 pages)

Birch, G., (2003). A scheme for assessing human impacts on coastal aquatic environments using sediments. in: Woodcoffe, C. D., Furness, R. A. (Eds.), Coastal GIS 2003. Wollongong University Papers in Center for Maritime Policy, 14, Australia.

Boyden, C. R.; Aston, S. R.; Thornton, I., (1979). Tidal and seasonal variation of trace elements in two Cornish estuaries. Estuarine Coast Mar. Sci., 9 (3), 303-317 (15 pages).

Bryan, G. W.; Langston, W. J., (1992). Bioavailability, accumulation and effects of heavy metals in sediments with special reference to United Kingdom estuaries: a review. Environ. Pollut., 76 (2), 89-131 (43 pages).

DOD, (2001). Coastal ocean monitoring and prediction system. Department of Ocean Development. Annual Report., 37-110.

Ergin, M.; Saydam, C.; Basturk, O.; Erdem, E.; Yoruk, R., (1991). Heavy metal concentrations in surface sediments from the two coastal inlets (Golden Horn Estuary and Izmit Bay) of the northeastern Sea of Marmara. Chem. Geo., 91 (3), 269-285 (16 pages).

Everaart, J. M.; Fischer, C. V., (1992). The distribution of heavy metals $(\mathrm{Cu}, \mathrm{Zn}, \mathrm{Cd}, \mathrm{Pb})$ in the fine fraction of surface sediments of the North Sea. Neth. J. Sea Res., 29 (4), $323-$ 331 (9 pages).

Fergusson, J. E., (1990). The heavy elements: Chemistry, environmental impact and health effects, Pergamon Press, Oxford, England.
Folk, R. L.; Ward, W. C., (1957). Brazos river bar: A study in the significance of grain size parameters. J. Sediment Petrol., 27 (1), 3-27 (25 pages).

Förstner, U.; Wittman, G. T. W., (1983). Metal Pollution in the Aquatic Environment. Springer Heidelberg., 486.

Gaillard, J. F.; Pauwells, H.; Michard, G., (1989). Chemical diagenesis of coastal marine sediments. Oceanol. Acta., 12, 175-187 (13 pages).

Gaudette, H. E.; Flight, W. R.; Toner, L.; Folger, D. W., (1974). An inexpensive titration method for the determination of organic carbon in recent sediments. J. Sediment Petrol., 44 (1), 249-253 (5 pages).

Gibbs, R. J., (1977). Transport phases of transition metals in the Amazon and Yukon Rivers. Geol. Soc. Am. Bull., 88 (6), 829-843 (14 pages).

Hakanson, L., (1980). Ecological risk index for aquatic pollution control. A sedimentological approach. Water Res., 14 (5), 975-1001 (26 pages).

Hart, B., (1982). Uptake of trace metals by sediments and suspended particulates: A review. Hydrobiologia., 91 (1), 299-313 (15 pages).

Horowitz, E.; Elrick, K., (1987). The relation of stream sediment surface area, grain size and surface area to trace element chemistry. Appl. Geochem., 2 (4), 437-451 (14 pages).

Jayapraksh, M., (2002). A geochemical assessment of heavy metal pollution in Ennore creek, North of Chennai, Tamil Nadu, India. Ph.D. Thesis. 46-47.

Jonathan, M. P.; Ram-Mohan, V., (2003). Heavy metals in sediments of the inner shelf off the Gulf of Mannar, southeast coast of India. Mar. Pollut. Bull., 46 (2), 258-268 (11 pages).

Kalavani, J., (2007). Pollution induced inter and intra specific changes in the benthic community structure in the Buckingham canal, Ennore. Ph.D. thesis., 73-74.

Keil, R. G.; Montlucon, D. B.; Prahl, F. R.; Hedges, J. I., (1994). Sorptive preservation of labile organic matter in marine sediments. Nature, 370, 549-552 (4 pages).

Krumbein, W. C.; Pettijohn, F. J., (1938). Manual of sedimentary petrography. D. Appleton Century Co. Inc., New York. 549-551.

Loring, D. H.; Rantala., (1992). Manual for the geochemical analyses of marine sediments and suspended particulate matter. Earth-Sci. Rev., 32 (4) 235-283 (49 pages).

Luoma, S. N.; (1990). Processes affecting metal concentrations in estuarine and coastal marine sediments. Heavy metal in the marine Environment., CRC press., Boca Raton, FL, 5166.

McKay, J. L.; Pedersen, T. F.; Mucci, A., (2007). Sedimentary redox conditions in continental margin sediments (N.E. Pacific) - Influence on the accumulation of redox-sensitive trace metals. Chem. Geol., 238 (3-4), 180-196 (17 pages).

Moore, P. A.; Reddy, K. R.; Fisher, M. M., (1989). Phosphorus flux between sediment and overlying water in Lake Okeechobee, Florida: spatial and temporal variations. J. Environ. Qual., 27 (6), 1428-1439 (12 pages).

Mucha, A. P.; Vasconcelos, M. T. S. D.; Bordalo, A. A., (2003). Macrobenthic community in the Doura estuary: Relations with trace metals and natural sediment characteristics. Environ. Pollut., 121 (2), 169-180 (12 pages).

Muller, G., (1979). Schwermetalle in den Sedimenten des Rheins Veranderungen seit. Umschau. 79 (24), 778-783 (6 pages). 
Muthumanickam, J., (2003). Geochemical assessment of heavy metal pollution in Ennore Creek, North of Chennai, India. University of Madras (India), 298.

Nadia, B. E.; Badr Anwar, A.; El-Fiky Alaa R.; Mostafa, Bandr A.; Al-Mur., (2009). Metal pollution records in core sediments of some Red Sea coastal areas, Kingdom of Saudi Arabia. Environ. Monit. Assess., 155 (1-4), 509-526 (18 pages).

Nouri, J.; Karbassi, A. R.; Mirkia, S., (2008). Environmental management of coastal regions in the Caspian Sea. Int. J. Environ. Sci. Tech., 5 (1), 43-52 (10 pages)

Nouri, J.; Mahvi, A. H.; Babaei, A.; Ahmadpour, E., (2006). Regional pattern distribution of groundwater fluoride in the Shush aquifer of Khuzestan County IranFluoride. Fluoride., 39 (4), 321-325 (5 pages).

Pekey, H., (2006). Heavy metal pollution assessment in sediments of Izmit Bay, Turkey. Environ. Monitor. Assess., 123 (1-3), 219-231 (13 pages).

Perin, G.; Bonardi, M.; Fabris, R.; Simoncini, B.; Manente, S.; Tosi, L.; Scotto, S., (1997). Heavy metal pollution in central Venice Lagoon bottom sediments: evaluation of the metal bioavailability by geochemical speciation procedure. Environ. Tech., 18 (6), 593-604 (12 pages).

Ruiz-Ferna'ndez, A. C.; Pa'ez-Osuna, F.; Hillaire-Marcel, C.; Soto-Jime'nez, M.; Ghaleb, B., (2001). Principal component analysis applied to assessment of metal pollution from urban wastes in the Culiaca'n river estuary. Bull. Environ. Contam. Toxicol., 67 (5), 741-748 (9 pages)

Samarghandi, M. R.; Nouri, J.; Mesdaghinia, A. R.; Mahvi, A. H.; Naseri, S.; Vaezi, F., (2007). Efficiency removal of phenol, lead and cadmium by means of UV/TiO2/H2O2 processes. Int. J. Environ. Sci. Tech., 4 (1), 10-25 (16 pages).

Schiff, K. C.; Weisberg, S. B., (1999). Iron as a reference element for determining trace metal enrichment in Southern California coast shelf sediments. Mar. Environ. Res., 48 (2), 161-176 (16 pages)

Spencer, K. L.; Macleod, C. L., (2002). Distribution and partioning of heavy metals in estuarine sediment cores and implications for the use of sediment quality guidelines. Hydrol. Earth System Sci., 6 (6), 989-998 (13 pages).

SPSS., (1995). Professional statistics 6.1. Marija J. Norusis/ SPSS Inc, Chicago.

Szefer, P.; Geldon, J.; Ahmed Ali, A.; Paez Osuna, F.; RuizFernandes, A. C.; GuerroGaivan, S. R., (1998). Distribution and association of trace metals in soft tissue and byssus of Mytella strigata and other benthal organisms from Mazatlan Harbour, Mangrove Lagoon of the northwest coast of Mexico. Environ. Int., 24 (3), 359-374 (16 pages).

Tam, N. F. Y.; Wong, Y. S., (2000). Spatial variation of heavy metals in surface sediments of Hong Kong mangrove swamps. Environ. Pollut., 110 (2), 195-205 (11 pages).

Taulis, M. E., (2005). Metal contaminants in leachate from sanitary landfills, in: Moore, T. A.; Black, A.; Centeno, J. A.; Harding, J. S.; Trumm, D. A. (Eds.), Metal contaminants in New Zealand, Resolutionz Press, Christchurch, New Zealand, 173-190.

Tomlinson, D. C.; Wilson, J. G.; Harris, C. R.; Jeffery, D. W., (1980). Problems in the assessment of heavy metals levels in estuaries and the formation of a pollution index. Helgol. Wiss. Meeresunters., 33 (1-4), 566-575 (10 pages) .

Turekian, K. K.; Wedepohl, K. H., (1961). Distribution of the elements in some major units of the Earth's crust. Bull. Geol. Soc. Am., 72 (2), 175-192 (18 pages).

Vinodhini, R.; Narayanan, M., (2008). Bioaccumulation of heavy metals in organs of fresh water fish Cyprinus carpio (Common carp). Int. J. Environ. Sci. Tech., 5 (2), 179-182 (4 pages).

Voutsinou-Taliadouri, F., (1995). A weak acid extraction method as a tool for the metal pollution assessment in surface sediments. Mikrochimica Acta., 119 (3-4), 243249 (7 pages).

Zvinowanda, C. M.; Okonkwo, J. O.; Shabalala, P. N.; Agyei, N.M., (2009). A novel adsorbent for heavy metal remediation in aqueous environments. Int. J. Environ. Sci. Tech. 6 (3), 425-434 (10 pages).

\section{AUTHOR (S) BIOSKETCHES}

Seshan, B. R. R., M.Phil., Ph.D. candidate, Research Scholar, Centre for Environmental Studies, Anna University Chennai, Chennai - 600 025. India. Email: mbseshu@rediffmail.com

Natesan, U., Ph.D., Professor, Centre for Environmental Studies, Deputy Director, Centre for Research, Centre for Environmental Studies, Anna University Chennai, Chennai - 600025 . India.

Email: u_natesan@yahoo.com

Deepthi, K., M.Sc., Ph.D. candidate, Research Scholar, Centre for Environmental Studies, Anna University Chennai, Chennai - 600025. India. Email: k_deepthi5@yahoo.co.in 